\title{
Author Correction: Collaborative networks in gene editing
}

Ying Huang, Alan Porter, Yi Zhang and Rodolphe Barrangou

Correction to: Nature Biotechnology https://doi.org/10.1038/s41587-019-0275-Z, published online 2 October 2019.

In the version of this article initially published, the affiliation for Eugene V. Koonin was given in Table 2 as Korea Centers for Disease Control \& Prevention. The correct affiliation is US National Center for Biotechnology Information, National Institutes of Health. The error has been corrected in the HTML and PDF versions of the article.

Published online: 14 November 2019

https://doi.org/10.1038/s41587-019-0353-2

( ) Springer Nature America, Inc. 2019

\section{Publisher Correction: Their lives in their hands}

Malorye Allison Branca

Correction to: Nature Biotechnology https://doi.org/10.1038/s41587-019-0303-z, published online 1 November 2019.

In the version of this article initially published, Leslie Gordon's MD degree was not mentioned and Maria Eriksson's name was misspelled Marie Erickson. The errors have been corrected in the HTML and PDF versions of the article.

Published online: 21 November 2019

https://doi.org/10.1038/s41587-019-0354-1

(๑) Springer Nature America, Inc. 2019 